ことが望ま机る，今回の研究からティシールは声帯粘 膜波動に障害をあたえずに良好な創傷治瘜をもたらす
ことがわかり，音声外科領域に扔いてもその有用性が 大いに期待された。

\title{
35. 粗梲性嗄声の病的声帯振動パタン
}

\section{——超高速ディジタル撮影——}

桐谷 滋・広瀬 㢣・今川 博（東大音声研）

目的 嗄生の生成要因を明らかにするには, 音声信 号と声带振動を同時記録して，その対応関係を解析す ることが必要である。我々は，声帯振動の高速度撮影 を簡便に行うために，ディジタル撮影方式を開発して いる. この装置は，従来の高速映画撮影に比心゙小型簡 便であり，また，雑音発生源がなく音声の同時録音を 簡単に行える等の特徵がある。今回は，この装置によ り主として粗䊁性嗄声の波形の変動パタンと声带振動 パタンの対応関係を観察した。

锶測琵置 側視鏡を一眼レフカメラボディに接続 し，カメラ内にイメージセンサを装着する。センサは 走査クロック最高 $10 \mathrm{MHz}$ のものを使用して扔り, $100 \times 36$ 画素で毎秒2000コマの撮影が可能である.光源 は 250W ハロゲンランプ 2 台を用いる. 画像信号は, $\mathrm{A} / \mathrm{D}$ 変換器を通じてイメージメモリに記憶される。記 憶したデー夕は，パーソナルコンピュータにより，再 生する。そのためにパーソナルコンピュータ用のビデ オ入出力ボードを使用し，画像デー夕を 1 コマずつボ ードに転送してスローモーション画像として表示す る.

観測結果 今回観測した例では，多くの場合波形の 変動が周期的であった。 その周期は，音声の基本周期 の 1 周期㧍き， 2 周期㧍きのものから $7 \sim 8$ 周期㧍き
のものまでちった。これらの例では，いずれも左右の 声帯の振動パタンが不均衡なことが認めら机た。声帯 振動の周期的な変動は，パタンとしては比較的小さな 変化であるがスローモーション表示ではその動的特徵 を視察により確認することができた，今回の症例のう ちいくつかでは, 音声波形上, 励振パタンの明確な周 期と、励振パタンが弱くて不明瞭な周期が交替して表 われるものがあった。それらの声帯振動について画像 の濃度信号を解析した結果，閉鎖の強い周期と閉鎖の 弱い周期とが交替しており，励振パタンの強さと対応 していることが確認された。またいくつかの症例では, 声門の前方と後方で開閉運動の位相が異なり，かつそ の関係が周期毎に異なっている例があった。このよう な振動パタンには, 声帯の厚さ方向だけでなく, 長さ 方向にも 2 以上の自由度を考慮した振動モデルが必要 である。質問 大森孝一(京大). 1) 粗䊁性嗄声 例では $2 \sim 3$ 周期に一度の規則的振動があるというが 粗鈢性嗄声はすべて，不規則な振動ではなく規則的な 振動があると考えるか。応答 粗鈢性嗄声では変 動パタンが周期的なことが多いと考える。ただし，各 周期毎の波形の再現性の程度には, 種々の程度があり， それが聴覚印象に関係している可能性がある.

\section{6. 気管支ファイバースコープ下の気管支歯冠異物の摘出例}

\section{大垣治幸・生野 登・宇野浩平・越井健司・平林秀樹・日野原 正（獨協医大・気管食道科）}

72歳の男性。歯科治療中に誤德した右下葉気管支内 の菌冠を，局所麻酔で気管支ファイバースコープトに W字型異物鉏子を用いて摘出した。これをビデオにて 供覧し，気管支ファイバースコープ下の異物摘出術の 適応と利点および久点について考察し発表した。

気管・気管支異物の摘出法に関する近年の傾向は， 秏児や小児に対しては ventilation bronchoscopeな どの硬性気管支鏡を用い全身麻酔下に行われ，成人に おいても全身麻酔，局所麻酔を問わず硬性気管支鏡が 用いられることが多い.しかし, 軟性気管支鏡 (flexible bronchofiberscope) の開発帷鉗子類の改良に伴い，局 所麻酔下に気管ファイバースコープを用い異物摘出に 成功したという症例も報告されているが，その実数は 少ない.
その理由として，気管・気管支異物症例の頻度は圧 倒的に小星に多く，局所麻酔では患児の協力が得難い ことや，解剖学的に気管内腔の径が小さいため，異物 摘出に十分な鉗子口有するような太い軟性気管支鏡 を使用した場合，搰気が不十分で危険であることなど から，本法は小見には不適であること，したがって成 人にのみ適応となるが，成人の気管・気管支異物症例 そのものが少ないため，軟性気管支鏡を用いた摘出例 の報告は少ないものと思われる。

しかしながら，本法は㟝断としての気管支鏡检直か らそのまま治療に移行でき，必ずしも入院の必要がな く，しかも全身麻酔が危険であると考えられるような 症例にも行え，局所麻酔下の硬性気管支鏡よりも身体 的にも精神的にも苦痛が少ないなどの利点があり，そ 
の適応を十分考慮して行えば, 今後も安全で有用な方 法であると結論した。質問 岡本康比古(大津市)。 唾液による視野のさまたげを防止する目的で，術前に 唾液分泌抑制処置行うか。応答前投薬は通常
の気管支鏡施行時は硫酸アトロピン，アタラックス $\mathrm{P}$ を用いるが，本症例は基礎に高血圧症を持つため，使 用していない.

\title{
37．気管腺様囊胞癌再発例の前腕皮弁による頸部食道再建の経験
}

\author{
越井健司・大垣治幸・藤沢 勉・中宗根康二・生野 登・宇野浩平 \\ 平林秀樹・日野原 正（獨協医大・気管食道科）
}

Adenoid cystic carcinoma (以下 ACC) の再発病変 の制御は非常に困難とされている。.今回われわれは 6 年前, 頸部気管の ACC で喉頭・頸部気管切除後, 食道

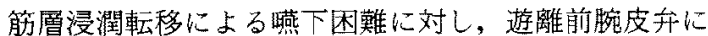
よる即時再建術を行い, 約 8 力月ぶりに常食摄取可能 となった症例を経験したので, その術前の食道造影, 頸部 CT, 手術術式および術後の内視鏡所見をビデオ で供覽した。

症例：72歳男性. 1983年頸部気管のACCで声門下 に進展していたため喉頭一気管の端々吻合ができず,喉 頭・頸部気管 ( 5 輪) 切除 (甲状腺左葉, 食道前壁一 部合併切除）を施行した。1988年12月頃から睘下時の つかえが出現し，永久気管孔直上の皮下に固い拇指頭 大，固定性の腫留を触れた。バリウム造影, 頸部 CTで 食道前壁に mass 認めた。本症例注初回手術の 1 年 後加ら胸部X線上ACCの遠隔転移と思われる multiple coin lesionがあったため手術には消極的で，外来 でCelestin dilatorによる保存的拡張索数回試み経過 をみていたところ，1989年 8 月，ミキサー食が鼻腔に
逆流し，体重も滅少してきたので，手術を目的に 8 月 下旬入院した。

術前の内視鏡所見では，食道前壁の圧排狭窄で内空 には顔を出していないと判断され，後壁を残して有茎 大胸筋皮弁か遊離前腕皮弁での再建を予定した。しか し，術中の迅速診断では後壁も残さず, $10 \times 10 \mathrm{~cm}$ の前 腕皮弁にて下咽頭・頸部食道を全周再建した。使用し た血管は，橈骨動脈と頸横動脈，伴走静脈と外頚静眽 を各々，顕微鏡下に吻合した。 4 週後の食道ファイバ 一スコピーにて上・下端とも良好な吻合部を確認した。 恵皮部の治痹を待って 8 週後に退院した。

まとめ 1) 本例のように遠隔転移があっても，そ の発育は緩慢であり，長期にわたって担癌生存するこ とがあるので局所再発に対しても積極的に十分な切除 を行うべきである．2）前腕皮弁は癭孔形成の危険标 あるが，比較的侵壟が少なく高龄者や全身状態の良く ない患者にも適する．3）今後も長期間にわたっての 観察を要する。

\section{Galeo-Periosteral Flap と遊離広背筋皮弁により}

\author{
再建した上顎癌進行症例 \\ 加藤孝邦・金子省三・清水佐和道・都志見 格（慈大）
}

上顎癌は局所浸潤傾向が強く, 従って䫒蓋内浸潤や 皮膚浸潤などに対しては拡大手術が行われている。し かも，その再建手術は遊離皮弁を用いるようになり， 容易に行えるようになった。最近我々は上䫑癌の進展 症例にたいし Galeo-Periosteal Flap にて頭蓋底を， 遊離広背筋皮弁にて鼻腔抒上び顔面の再建を一期的に 行い良好であったので本症例の概要を報告した。

症例：36歳男性. 主訴：鼻閉, 流滬. 起始抒上び経過： 約 1 年前より軽度の鼻閉があったが放置していた。約 3力月前上り鼻閉注著しくなり，鼻汁も多くなった。 2力月前上り流滬, 眼球突出, 複視が出現したために 眼科を受診し，耳鼻科を紹介され当科を受診した。

初診時顔面皮膚に腫县は浸潤し, 潰怚を形成してい た。鼻内は下甲介が外側より圧迫され，浮腫状であっ た、、蓋には浸潤はなかった。頸部りンパ節を触知し
た.CT,MRIにて篩骨洞天盖の浸潤による骨欠損が認 められた。しかし頭蓋内浸潤は認められなかった。 左 上深頸りンパ節を触知した。

浅側頭動脈より CDDP と5FUの動注と術前照射 40Gy 後に手術を行った。手術法まず頭部冠状切開に より Galeo-Periosteal Flap を作成した。次に Frontal Graniotomy を行い, 脳硬膜を前頭蓋底より剝離した。 このとき後部篩骨洞の位置で軽度の䄖着が認められた が，硬膜への浸潤範囲はわずかであり，この部の硬膜 を切除した．脳硬膜は縫縮することが出来たので摘出 手術に移った。摘出手術は眼球摘出を含む上頻拡大全 摘を行い，篩骨洞天蓋に脳硬膜をつけて摘出した。摘 出手術後に最初に作成しておいた Galeo-Periosteal Flap を用いて,その間に頭蓋骨外板を組織接着剤にて 固定し再建した。上顎拡大全摘にて久損した顔面の再 